\title{
MALT1 Gene
}

National Cancer Institute

\section{Source}

National Cancer Institute. MALT1 Gene. NCI Thesaurus. Code C60671.

This gene plays a role in signal transduction and in the pathology of mucosa-associated lymphoid tissue lymphomas. 